\title{
Intra-tumoral IFN- $\gamma$-producing Th22 cells correlate with TNM staging and the worst outcomes in pancreatic cancer
}

\author{
Elena Niccolai*, Antonio Taddei†, Federica Ricci*, Simona Rolla §, Mario Milco D'Elios*\|,

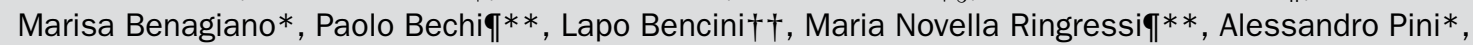

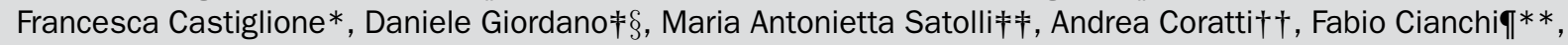 \\ Daniele Bani*, Domenico Prisco*\|, Francesco Novelli†キ£ and Amedeo Amedei*\| \\ *Department of Experimental and Clinical Medicine, University of Florence, Largo Brambilla 3, 50134 Florence, Italy \\ †Immunogenetics and Transplant Biology Service, Azienda Ospedaliera Città della Salute e della Scienza di Torino, via Santena 19,10126 Turin, Italy \\ キCentre for Experimental Research and Medical Studies (CERMS), Azienda Ospedaliera Città della Salute e della Scienza di Torino, via Cherasco 15 \\ 10126 Turin, Italy \\ $\S$ Molecular Biology Center and Department of Molecular Biotechnology and Health Sciences, University of Turin, via Nizza 52, 10126 Turin, Italy \\ ॥Department of Neuro-Skeletal Muscle and Sensory Organs, Interdisciplinary Internal Medicine Unit, Azienda Ospedaliero Universitaria Careggi, \\ 50134 Florence, Italy \\ ףDepartment of Surgery and Translational Medicine, University of Florence, Viale Michelangiolo 41, 50125 Florence, Italy \\ **Department of Biomedicine, Azienda Ospedaliera Universitaria Careggi (AOUC), Largo Brambilla 3, 50134 Florence, Italy \\ ††Department of Oncology, Division of General and Oncologic Surgery, Azienda Ospedaliera Universitaria Careggi (AOUC), Largo Brambilla 3, 50134 \\ Florence, Italy \\ キキentro Oncologico Ematologico Subalpino (COES), AOU Città della Salute e della Scienza di Torino, 10126 Turin, Italy
}

\begin{abstract}
PDAC (pancreatic ductal adenocarcinoma) is the fifth leading cause of cancer-related death. The causes of this cancer remain unknown, but increasing evidence indicates a key role of the host immune response and cytokines in human carcinogenesis. Intra-tumoral IL (interleukin)-22 levels have been shown to be elevated in PDAC patients. However, little is known regarding the expression and clinical relevance of Th2 2 cells in human PDAC and, furthermore, which TILs (tumour-infiltrating lymphocytes) are the main producers of IL-22 is unknown. In the present study, we characterized the functional proprieties of the different subsets of IL-22-producing TILs and analysed their relationship with the TNM staging system and patient survival. We have demonstrated for the first time that, in PDAC patients, the T-cells co-producing IFN- $\gamma$ (interferon $\gamma$ ) and exerting perforin-mediated cytotoxicity are the major intra-tumoral source of IL-22. In addition, isolated Th22 cells were able to induce apoptosis, which was antagonized by IL-22. Finally, we observed that the IL-22-producing T-cells were significantly increased in tumour tissue and that this increase was positively correlated with TNM staging of PDAC and poorer patient survival. These novel findings support the dual role of the anti-tumour immune system and that IL-22-producing cells may participate in PDAC pathogenesis. Therefore monitoring Th22 levels could be a good diagnostic parameter, and blocking IL-22 signalling may represent a viable method for anti-PDAC therapies.
\end{abstract}

Key words: IFN- $\gamma$, IL-22, pancreatic cancer, Th22, tumour-infiltrating lymphocytes.

\section{INTRODUCTION}

Pancreatic cancer is the fifth leading cause of cancer-related death in the developed world, with more than 260000 annual deaths worldwide [1] and with a dismal 5-year survival (5\%). The lethality of pancreatic cancer is due to its aggressive nature and its tendency to remain asymptomatic until the tumour reaches an advanced stage, limiting the likelihood of early diagnosis. At the time of initial presentation, most pancreatic cancers are locally advanced or metastatic and need multimodal therapy [2], hence the need to find factors that may facilitate earlier diagnosis and improve prognosis of this neoplasia.

Pancreatic cancer originates in the ductal epithelium and evolves from a pre-malignant lesion to fully invasive cancer. The causes of pancreatic cancer remain unknown, although some studies have shown that chronic inflammation is a common

Abbreviations: BFA, brefeldin A; FoxP3, forkhead box P3; IFN- $\gamma$, interferon $\gamma$; IL, interleukin; IL-10R2, IL-10 receptor 2; IL-22R, IL-22 receptor; mAb, monoclonal antibody; PBMC, peripheral blood mononuclear cell; PD-1, programmed cell death 1; PDAC, pancreatic ductal adenocarcinoma; Tcc, T-cell clone(s); Th, T helper; TIL, tumour-infiltrating lymphocyte.

Correspondence: Professor Amedeo Amedei (email aamedei@unifi.it) or Professor Francesco Novelli (email franco.novelli@unito.it). 
feature of actively growing pancreatic tumours [3]. Moreover, increasing evidence has shown that the host immune response and related inflammatory and immune mediators, such as cytokines, participate in human carcinogenesis [4,5]. IL (interleukin)-22, which belongs to the IL-10 cytokine family, is a T-cell-derived cytokine that mediates epithelial immunity and mucosal tissue repair [6]. IL-22 triggers intracellular signalling by binding to a heterodimeric receptor complex that is composed of IL-22R1 (IL-22 receptor 1) and IL-10R2 (IL-10 receptor 2) [7]. However, the cellular responsiveness of IL-22 is mainly determined by IL-22R1, which is selectively expressed on non-immune cells [8], such as hepatocytes [9], keratinocytes [10], colonic epithelial cells [11] and, particularly, pancreatic cells $[12,13]$.

Principal sources of IL-22 include CD4 ${ }^{+}$Th (T helper) cells, $\mathrm{CD}^{+}$CTLs (cytotoxic T-cells), $\gamma \delta$ T-cells and ILCs (innate lymphoid cells), encompassing NK (natural killer) cells, LTi (lymphoid tissue inducer)-like cells $[14,15]$ and NKT (natural killer T) cells [16]. Although several IL-22-producing CD4 ${ }^{+}$ T-cells also produce other cytokines, such as IL-17 or IFN- $\gamma$ (interferon $\gamma$ ) [17], some, only secrete IL-22 [18]. These CD4 ${ }^{+}$ T-cells that exclusively secrete IL-22 are known as Th22 cells and have been recently identified as the main producers of IL-22 in the peripheral blood $[19,20]$. Th22 cells play important roles in many inflammatory diseases, such as psoriasis [21], rheumatoid arthritis [22] and multiple sclerosis [23]. Moreover, IL-22 plays a pro-tumour role in cancers of the gastrointestinal tract. Gastric tumours show increased infiltration of Th22, which correlates with tumour stage and poor prognosis [24]. In addition, compared with healthy controls, gastric cancer patients also have higher circulating frequencies of IL-17- and IL-22-producing T-cells, which are positively associated with cancer stage and negatively with patient survival [25]. In colorectal cancer, levels of both IL-17 and IL-22 are positively correlated with the tumour stage [26], and serum IL-22 is elevated in chemoresistant patients [27]. Moreover, IL-22 administration to human colorectal cancer cell lines renders them chemoresistant [27]. In pancreatic cancer, intra-tumoral IL-22 levels and frequency of Th22 cells are elevated compared with the peripheral blood of patients and healthy donors [28]. Similarly, expression of both IL-22 and IL-22R1 is elevated in tissue sections of PDAC (pancreatic ductal adenocarcinoma) tissue [29]. However, little is known regarding the expression and clinical relevance of $\mathrm{Th} 22$ in pancreatic cancer and, furthermore, which TILs (tumour-infiltrating lymphocytes) are the main producers of IL-22 is unknown. In the present study, we have investigated the role of IL-22-producing T-cells during PDAC progression. In detail, we have characterized the functional proprieties of the different subsets of IL-22-producing $\mathrm{CD}^{+}$and $\mathrm{CD}^{+}$Tcc (T-cell clones) generated from lymphocytes that infiltrate PDAC tissue, and we analysed their relationship with the TNM staging system and patient survival.

\section{MATERIALS AND METHODS}

\section{Patients}

Tumours and corresponding adjacent tissues were obtained from 30 PDAC patients (14 males and 16 females), who were classified according to the TNM classification for pancreatic tumours [30]. The mean age of the PDAC patients was 66 years (range 3692 years). The clinical characteristics of patients are summarized in Table 1. All patients underwent surgical resection of the primary lesion, but did not receive chemotherapy. Patients with evidence of serious illness, immunosuppression, or autoimmune or infectious diseases were excluded. The study was approved by the local Ethical Committees (Azienda Ospedaliera Universitaria Careggi) and informed consent was obtained from all patients.

\section{Generation of Tcc from TILs of the neoplastic pancreatic tissue}

T-cell cultures were performed in RPMI 1640 culture medium (SERO-Med) supplemented with $10 \%$ (v/v) HyClone ${ }^{\mathrm{TM}}$ FBS (Gibco Laboratories) and recombinant human IL-2 (EuroCetus). Surgical specimens of PDAC tissue were cultured for 7 days in RPMI 1640 medium supplemented with IL-2 (50 units/ml), in order to expand in vivo-activated TILs; in detail, tissue pieces from each patient were obtained from two different sites, namely tumour and surrounding healthy mucosa. Each specimen was then disrupted, and single T-cell blasts were cloned under limiting dilution, as described previously [31]. Briefly, single T-cell blasts were seeded in microwells $(0.3$ cell/well $)$ in the presence of $2 \times 10^{5}$ irradiated (9000 rad) PBMCs (peripheral blood mononuclear cells), PHA (phytohaemagglutinin) (0.5\%) and IL-2 (50 units $/ \mathrm{ml})$. At weekly intervals, $2 \times 10^{5}$ irradiated PBMCs and IL-2 were added to each micro-culture to maintain the expansion of growing clones. The Tcc were evaluated for their surface markers and functional proprieties, namely cytokine profile, B-cell helper activity and cell cytotoxicity.

\section{Analysis of cell-surface markers and evaluation of the cytokine profile of isolated Tcc}

Fluorochrome-conjugated anti-CD3, -CD4, -CD8 and isotypematched control mAbs (monoclonal antibodies) were purchased from BD Biosciences. We analysed surface marker (CD3, CD4 and CD8) expression in blasts of single Tcc by flow cytometry, as described previously [31]. To evaluate the amount of secreted cytokines, T-cell blasts of single Tcc were resuspended at a concentration of $10^{6}$ cells $/ \mathrm{ml}$ of medium and cultured for $36 \mathrm{~h}$ in the presence of PMA $(10 \mathrm{ng} / \mathrm{ml})$ plus ionomycin $(200 \mathrm{ng} / \mathrm{ml})$. Cell-free supernatants were collected and assayed in duplicate for IFN- $\gamma$, IL-4, IL-17 and IL-22 content using commercial ELISA kits (Bio-Source International). Supernatants presenting cytokine levels that were 5 S.D. above the mean levels of control supernatants derived from irradiated APCs (antigen-presenting cells) alone were regarded as positive. On the basis of the evaluation of the cytokine profile and the CD4/CD8 expression, we divided the clones into the following groups: Th22/Tc22 (only IL-22), Th22Th1/Tc22Tc1 (IL-22+IFN- $\gamma$ ), Th22Th2/Tc22Tc2 (IL22+IL-4), and Th22Th17/Tc22Tc17 (IL-22+IL-17).

\section{B-cell helper activity}

B-cells were prepared using the B-cell isolation kit II (Miltenyi Biotec). A total of $2 \times 10^{5}$ B-cells were co-cultured with $10^{5}$ 


\begin{tabular}{|c|c|c|c|c|c|c|c|c|}
\hline Code & Age & Sex & TNM & $\begin{array}{l}\text { Tumour } \\
\text { size } \\
\text { (cm) }\end{array}$ & Metastasis & $\begin{array}{l}\text { Overall } \\
\text { Survival } \\
\text { (months) }\end{array}$ & $\begin{array}{l}\text { Tcc } \\
\text { obtained }\end{array}$ & $\begin{array}{l}\text { IL-22-producing } \\
\text { Tcc }(\%)\end{array}$ \\
\hline 01.PDAp & 50 & Male & pT1, N1, Mx & $>3$ & - & 11 & 84 & $12(14)$ \\
\hline 02.PDAp & 73 & Male & pT2, N1, Mx & $>3$ & - & 13 & 26 & $4(15)$ \\
\hline 03.PDAp & 56 & Male & pT3, NO, Mx & $>3$ & ++ & 8 & 6 & $4(67)$ \\
\hline 04.PDAp & 36 & Male & pT4, N1, M1 & $\leqslant 3$ & ++ & 7 & 16 & $10(63)$ \\
\hline 05.PDAp & 74 & Female & pT3, N1, Mx & $>3$ & ++ & 9 & 91 & $55(60)$ \\
\hline 06.PDAp & 61 & Female & pT4, N1, Mx & $>3$ & ++ & 8 & 20 & $10(50)$ \\
\hline 07.PDAp & 63 & Male & pT1, N1, Mx & $>3$ & - & 12 & 37 & $8(22)$ \\
\hline 08.PDAp & 74 & Female & pT4, NO, Mx & $>3$ & ++ & 8 & 74 & $44(59)$ \\
\hline 09.PDAp & 54 & Female & pT2, NO, Mx & $>3$ & - & 14 & 5 & $1(20)$ \\
\hline 10.PDAp & 92 & Male & pT3, N1, Mx & $\leqslant 3$ & ++ & 9 & 3 & $2(67)$ \\
\hline 11.PDAp & 57 & Male & $\mathrm{pT} 2, \mathrm{~N} 1, \mathrm{M} 1$ & $\leqslant 3$ & + & 10 & 22 & $8(36)$ \\
\hline 12.PDAp & 51 & Female & pT1, N1, Mx & $>3$ & - & 11 & 13 & $2(15)$ \\
\hline 13.PDAp & 72 & Female & pT4, N1, Mx & $>3$ & ++ & 8 & 22 & $15(68)$ \\
\hline 14.PDAp & 80 & Female & pT2, N1, M1 & $\leqslant 3$ & - & 12 & 58 & 11 (19) \\
\hline 15.PDAp & 58 & Male & pT1, NO, Mx & $\leqslant 3$ & + & 13 & 28 & $9(32)$ \\
\hline 16.PDAp & 55 & Female & pT1, NO, Mx & $\leqslant 3$ & - & 13 & 11 & $2(18)$ \\
\hline 17.PDAp & 70 & Female & pT2, N1, Mx & $>3$ & + & 11 & 32 & $8(25)$ \\
\hline 18.PDAp & 62 & Female & pT3, NO, Mx & $>3$ & ++ & 8 & 24 & $14(58)$ \\
\hline 19.PDAp & 42 & Female & $\mathrm{pT} 4, \mathrm{~N} 1, \mathrm{M} 1$ & $>3$ & ++ & 9 & 10 & $6(60)$ \\
\hline 20.PDAp & 58 & Male & pT1, NO, Mx & $>3$ & - & 11 & 52 & $13(25)$ \\
\hline 21.PDAp & 74 & Male & pT4, N1, Mx & $>3$ & ++ & 8 & 31 & $25(81)$ \\
\hline 22.PDAp & 79 & Female & pT4, N1, Mx & $\leqslant 3$ & + & 10 & 28 & $14(50)$ \\
\hline 23.PDAp & 83 & Male & pT4, NO, Mx & $>3$ & ++ & 8 & 22 & $15(68)$ \\
\hline 24.PDAp & 62 & Male & pT1, NO, Mx & $>3$ & - & 12 & 12 & $1(8)$ \\
\hline 25.PDAp & 85 & Female & pT1, NO, Mx & $\leqslant 3$ & + & 13 & 8 & $3(38)$ \\
\hline 26.PDAp & 76 & Male & $\mathrm{pT} 2, \mathrm{~N} 1, \mathrm{M} 1$ & $\leqslant 3$ & + & 12 & 18 & $8(44)$ \\
\hline 27.PDAp & 71 & Male & pT1, N1, Mx & $\leqslant 3$ & + & 11 & 7 & $2(29)$ \\
\hline 28.PDAp & 63 & Female & pT3, N1, Mx & $>3$ & ++ & 8 & 11 & $7(64)$ \\
\hline 29.PDAp & 66 & Female & $\mathrm{pT} 2, \mathrm{~N} 1, \mathrm{M} 1$ & $\leqslant 3$ & - & 14 & 32 & $8(25)$ \\
\hline 30.PDAp & 72 & Female & pT4, N1, Mx & $\leqslant 3$ & + & 8 & 4 & $2(50)$ \\
\hline $\begin{array}{l}\text { All PDAC } \\
\text { patients }\end{array}$ & 66 & $\begin{array}{l}14 \text { male } / 16 \\
\text { female }\end{array}$ & $\begin{array}{l}\text { Pancreatic ductal } \\
\text { adenocarcinoma }\end{array}$ & & & 10.3 & 807 & $323(40)$ \\
\hline
\end{tabular}

blasts of the different Th22/Tc22 Tcc subsets and stimulated with $100 \mathrm{ng} / \mathrm{ml}$ anti-CD3 mAb. On day 7, supernatants from each cell culture were collected and evaluated by ELISA for $\operatorname{IgM}, \operatorname{IgG}$, $\operatorname{IgA}$ and $\operatorname{IgE}$ content.

\section{Flow cytometric detection of granzyme $A$ and evaluation of cell cytotoxicity}

Granzyme A expression by Tcc was assessed according to the manufacturer's instructions (BD Biosciences). The different subpopulations of IL-22-producing Tcc were tested for their ability to kill P815 target cells upon anti-CD3 mAb activation $(5 \mu \mathrm{g} / \mathrm{ml})$ by evaluating the percentage of annexin V-binding cells using flow cytometry. The evaluation of apoptosis in Tcc and in L3.6pl tumour cells was performed using the Annexin V kit (BD Biosciences) following the manufacturer's instructions. Cells were then analysed on a FACSCanto cytofluorimeter (BD Biosciences) using FACSDiva software.

\section{Tumour cell cultures and in vitro cytotoxicity assay}

Human PDAC L3.6pl cells (cell line kindly provided by Professor Paola Nisticò, Regina Elena National Cancer Institute, Rome, Italy) were cultured in DMEM (Dulbecco's modified Eagle's medium) (Lonza) supplemented with 10\% (v/v) FBS (Lonza), L-glutamine (GE Healthcare) and $50 \mu \mathrm{g} / \mathrm{ml}$ gentamicin (Gentalyn $40 \mathrm{mg} / \mathrm{ml}$, Essex Italia) at $37^{\circ} \mathrm{C}$ in a $5 \% \mathrm{CO}_{2}$ atmosphere. For the cytotoxicity assay, cells were seeded in 96-well plates at a density of $2 \times 10^{4}$ cells per well, incubated for $4 \mathrm{~h}$ and then starved overnight at $37^{\circ} \mathrm{C}$. Cells were treated with $100 \mathrm{ng} / \mathrm{ml} \mathrm{IL-22}$ or IFN $\gamma$, or both, and incubated for $72 \mathrm{~h}$; cell viability was then determined using the MTT assay (Sigma). Briefly, $20 \mu \mathrm{l} /$ well of $5 \mathrm{mg} / \mathrm{ml}$ MTT solution in PBS was added and incubated for $4 \mathrm{~h}$ 
at $37^{\circ} \mathrm{C}$. Medium was removed and $100 \mu 1$ of DMSO was added to each well. The formazan salts were quantified by reading the absorbance at a test wavelength of $570 \mathrm{~nm}$.

\section{Immunohistochemical analysis}

The surgical specimens of PDAC tissue were fixed in $4 \%$ paraformaldehyde overnight at $4{ }^{\circ} \mathrm{C}$, paraffin-embedded and cut using a rotary microtome (MR2, Boeckeler Instruments). For immunohistochemical staining, $5-\mu \mathrm{m}$ sections of the blocks were incubated overnight with rabbit anti-human PD-1 (programmed cell death 1) mAb (clone EPR4877, 1:500 dilution; Abcam) or mouse anti-human FoxP3 (forkhead box P3) mAb antibody (clone 22510, $5 \mu \mathrm{g} / \mathrm{ml}, 1: 200$ dilution; Abcam); mouse anti-human CD4 $\mathrm{mAb}$ (neat, clone 4B12; Nichirei); mouse-anti-human CD8 mAb (1:20 dilution, Dako Japan) or mouse anti-human CD163 antibody (1:100 dilution, Leica Biosystems). Following antibody incubation, samples were incubated at room temperature for $1 \mathrm{~h}$ with anti-rabbit or anti-mouse immunoglobulins conjugated to a horseradish peroxidase-labelled dextran polymer (Simple Staining Kit; Nichirei). After a benzidine reaction, sections were lightly counterstained with haematoxylin.

For analysing the IL-22+ T-cells, sections were boiled for $10 \mathrm{~min}$ in sodium citrate buffer $(10 \mathrm{mM}, \mathrm{pH} 6.0$; Bio-Optica) for antigen retrieval, and incubated in $2 \mathrm{mg} / \mathrm{ml}$ glycine (AppliChem) for $10 \mathrm{~min}$, to quench autofluorescence of the elastic fibres. Non-specific binding was blocked by exposure to $1.5 \%$ BSA in PBS for $20 \mathrm{~min}$ at room temperature. Sections were immunolabelled overnight at $4{ }^{\circ} \mathrm{C}$ with mouse anti-CD3 $\mathrm{mAb}$ (ready to use; GeneTex) and goat polyclonal anti-IL-22 $\mathrm{mAb}$ (1:50 dilution; Abcam). Immunoreactions were visualized by incubation with specific anti-mouse and anti-goat Alexa Fluor® 488- or 568-conjugated IgG (1:300 dilution; Molecular Probes) for $2 \mathrm{~h}$ at room temperature. Negative controls were carried out by replacing the primary antibodies with non-immune serum. Digital images were obtained using an epifluorescence Zeiss Axioskop microscope equipped with a $\times 63$ oil-immersion objective.

\section{Staining of peripheral Th22 cells}

PBMCs were isolated by density gradient centrifugation from heparinized venous blood of PDAC patients or healthy subjects. PBMC samples were characterized for their expression of IL-22, IL-17 and IFN- $\gamma$ using intracellular cytokine staining, as described previously [23]. Briefly, fresh or thawed PBMCs were cultured in IMDM (Iscove's modified Dulbecco's medium) (BioWhittaker) supplemented with 10\% FBS (Invitrogen) and stimulated for $5 \mathrm{~h}$ with PMA $(50 \mathrm{ng} / \mathrm{ml})$ and ionomycin $(500 \mathrm{ng} / \mathrm{ml})$ in the presence of BFA (brefeldin A) $(10 \mu \mathrm{g} / \mathrm{ml})$ (all from Sigma-Aldrich). Cells were first stained for the surface antigens CD4 (BD Biosciences), then fixed with $4 \%$ (w/v) paraformaldehyde and permeabilized with $0.5 \%$ saponin, followed by intracellular staining with anti-IL-22, anti-IL-17 and anti-IFN- $\gamma$ mAbs (BD Biosciences).

\section{Statistical analysis}

Results are expressed as the median (range) or the mean ( \pm S.D.). Comparisons between the two groups were assessed using Stu- dent's $t$ test. Correlations between the parameters were assessed using Pearson's correlation analysis. SPSS statistical software (version 13.0) was used for all statistical analyses.

\section{RESULTS}

\section{Isolation of IL-22-producing T-cells from PDAC tissue}

To evaluate the intra-tumoral subsets of IL-22-producing (IL$22^{+}$) T-cells in PDAC patients, we expanded and cloned in vivoactivated TILs isolated from two different sites, namely tumour and surrounding healthy pancreas. We isolated Tcc from each patient, and overall we obtained $807 \mathrm{Tcc}$; of these Tcc, 507 were isolated from the cancer, which was almost double the number of the Tcc isolated from the healthy pancreas (300) (Table 1). Evaluating the surface markers of Tcc, we noticed that 710 (out of 807) (88\%) were positive for CD4 and the remaining 97 were positive for CD8 (12\%). After mitogen stimulation, we assessed the levels of IL-22 secreted by single Tcc. We observed that $323 \mathrm{Tcc}(40 \%)$ were able to produce IL-22 and, more precisely, $290 \mathrm{CD}^{+}$and $33 \mathrm{CD}^{+}$(Figure 1A). Of particular interest, the number of Th22 cells increased at the cancer site; we isolated $215(74 \%)$ Th22 Tcc from the tumour and only 75 (26\%) from the healthy mucosa. In addition, we registered similar data on the $\mathrm{CD}^{+}$population, isolating 25 out of $33(76 \%)$ from the neoplastic tissue and only $8(24 \%)$ from the surrounding healthy pancreatic tissue. Subsequently, we evaluated the IL-22 levels secreted by the Tcc, and we found that the IL-22producing Tcc (both $\mathrm{CD}^{+}$and $\mathrm{CD}^{+}$) isolated from the tumour tissue significantly $(P<0.0001)$ produced higher levels of IL-22 compared with the Tcc generated from the healthy pancreas (Figure 1B).

\section{Characterization of the cytokine profile of IL-22-producing Tcc}

As different T-cell subsets are able to produce IL-22, we also evaluated which of the 323 IL-22-producing Tcc also produced other cytokines. We observed that 61 (21\%) out of $290 \mathrm{CD}^{+}{ }^{+} \mathrm{Tcc}$ only secreted IL-22 (pure Th22), whereas 12 (4\%) co-secreted IL-4 (Th22/Th2), nine (3\%) co-secreted IL-17 (Th22/Th17) and $44 \%(128 / 290)$ of the IL-22-producing Tcc were able to cosecrete IFN- $\gamma$ (Th22/Th1). The remaining 80 (28\%) CD4 ${ }^{+}$Tcc co-produced IFN- $\gamma$ and IL-17 (Th22/Th1/Th17) (Figure 2A). Out of the 33 IL-22 ${ }^{+} \mathrm{CD}^{+}$Tcc, we found that $19(58 \%)$ Tcc coproduced IFN- $\gamma$ (Tc22/Tc1), four (11\%) synthesized both IFN- $\gamma$ and IL-17 (Tc22/Tc1/Tc17) and five (15\%) also produced IL-4 (Tc22/Tc2). The final five CD8 ${ }^{+}$Tcc $(16 \%)$ were only able to secrete IL-22 (Tc22) (Figure 2A).

\section{The IL-22-producing Tcc subsets exhibit different functional properties}

To define the functional properties of IL-22-producing Tcc, we then evaluated their ability to assist antibody production by B-cells and to display cytotoxic activity, which we then compared between the different IL-22 ${ }^{+}$Tcc. Both Th22/Th2 and 
A)

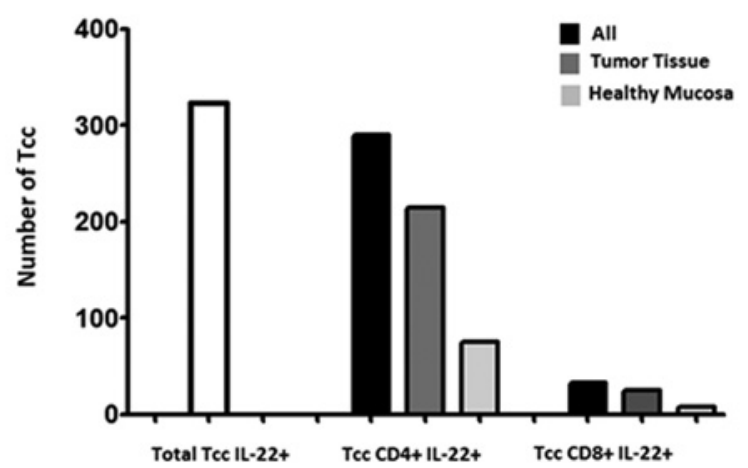

B)

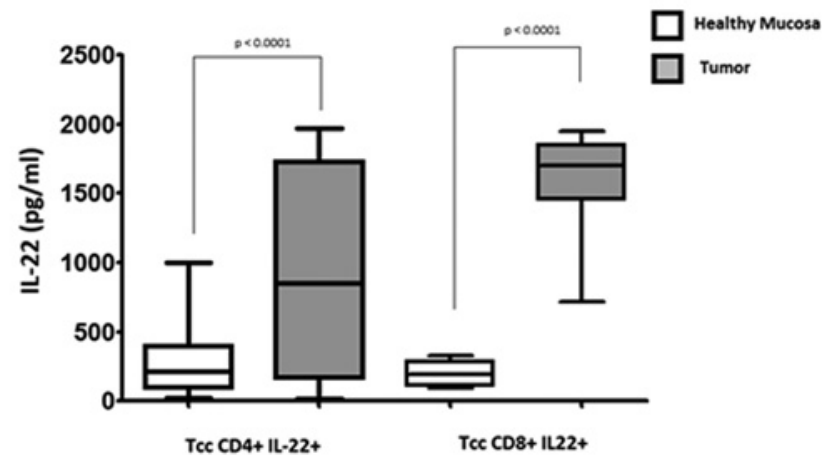

Figure 1 Repertoire and IL-22 production of Tcc obtained from PDAC patients

(A) Total numbers of IL-22+ Tcc isolated from tumour tissue and the ratio of $\mathrm{CD} 4^{+} / \mathrm{CD} 8^{+}$populations. The number of both $\mathrm{CD}^{+}$and $\mathrm{CD}^{+} \mathrm{IL}^{-22^{+}}$Tcc is higher in the cancer site. (B) Evaluation and comparison of the amount of IL-22 secreted, after mitogen stimulation, by the Tcc isolated from tumour tissue or surrounding healthy mucosa. The quantity of IL-22 produced by the Tcc (both $\mathrm{CD} 4^{+}$and $\left.\mathrm{CD}^{+}\right)$of tumour tissue is significantly $(P<0.0001)$ higher than that of Th22 cells isolated from healthy mucosa.

A)

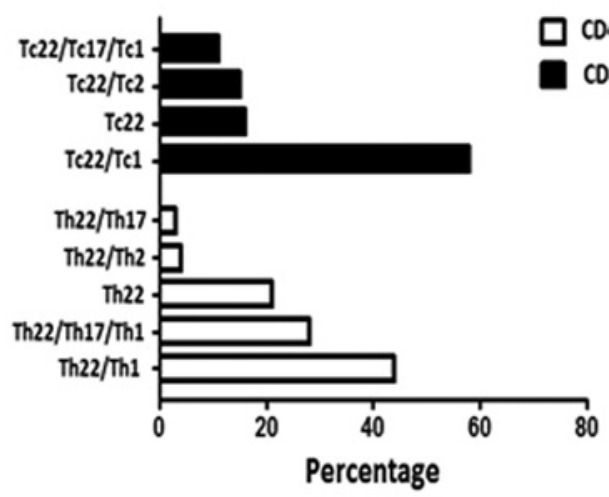

C)

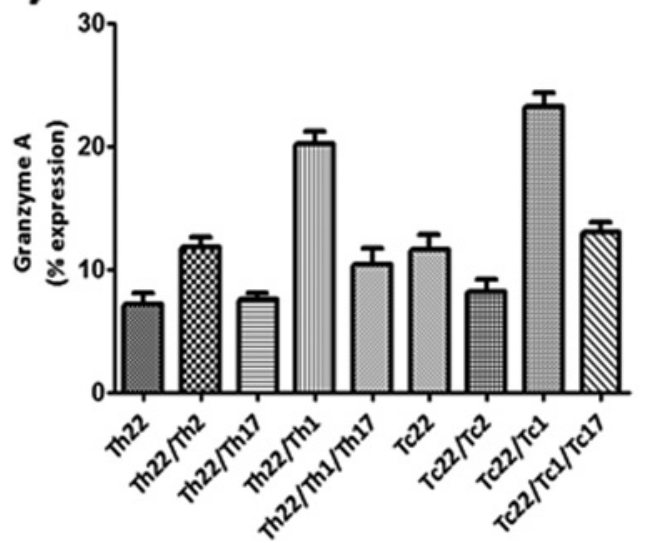

B)

$\mathrm{CO} 4+\mathrm{TCC}$

$\mathrm{COS}+\mathrm{TCC}$

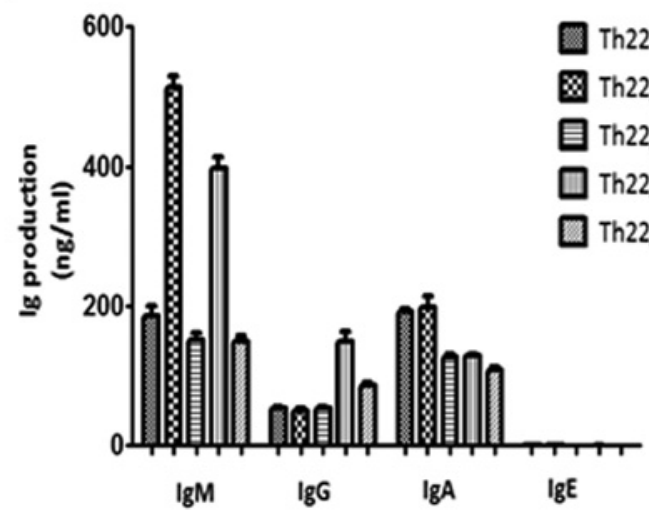

D)

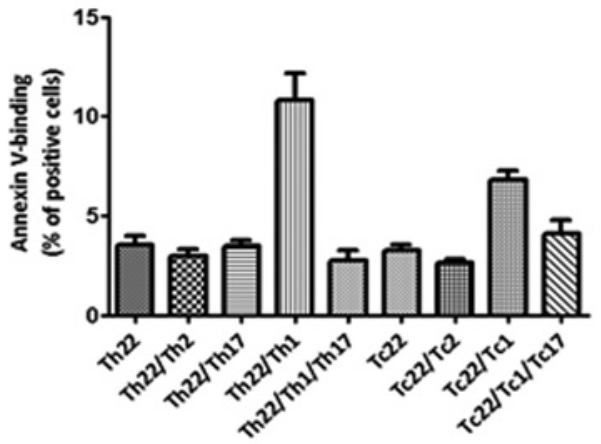

Figure 2 Cytokine profile and functional profile of intra-tumoral Th22 isolated from PDAC patients

(A) Distribution of Th22 subsets. The major representative Tcc subtype is the Th22 with Th1 profile, for both the CD4 ${ }^{+}$ population (white column) and the CD8+ population (black column). The percentage of Tcc producing only IL-22 (by our definition, pure Th22) is 21 of $\mathrm{CD} 4^{+}$Th22 and 16 of $\mathrm{CD} 8^{+}$Tc22. (B) To assess the B-cell helper activity, we used autologous B-cells co-cultured with $10^{5}$ blasts of the different Th22/Tc22 Tcc subsets, stimulated with anti-CD3 antibody. The supernatant content of different Ig subclasses was evaluated by commercial ELISA. (C) The granzyme A expression and the percentage of annexin V-binding cells $(\mathbf{D})$ were assessed according to the manufacturer's instructions (BD Biosciences) and analysed on a FACSCanto cytofluorimeter (BD Biosciences) using FACSDiva software. 
A)

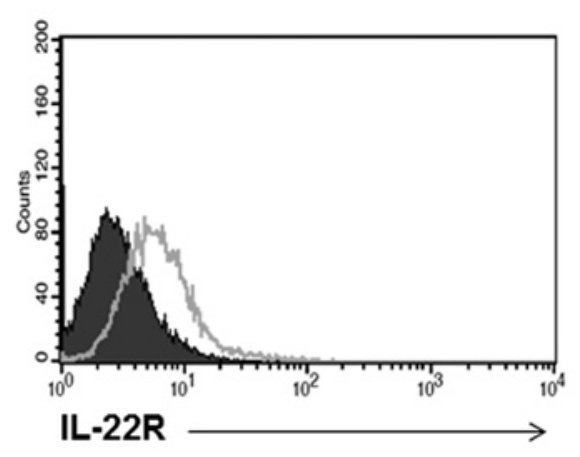

B)

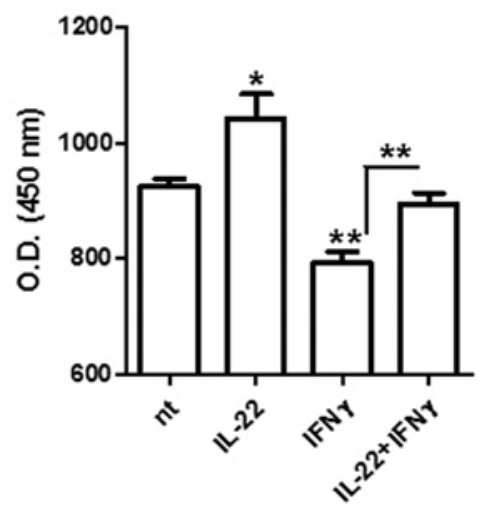

C)

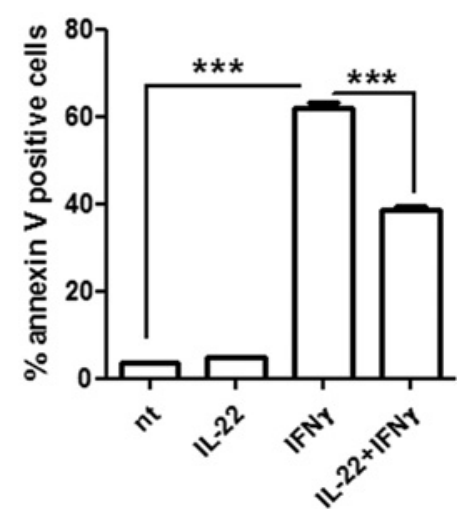

Figure 3 IL-22 reduced IFN- $\gamma$-induced apoptosis in the L3.6pl pancreatic tumour cell line

(A) Surface expression of IL-22R on L3.6pl cells after incubation with anti-IL-22R mAb (open curve) or isotype control (closed curve). L3.6pl cells were treated with IL-22 $(100 \mathrm{ng} / \mathrm{ml})$, IFN- $\gamma(100 \mathrm{ng} / \mathrm{ml})$ or both for $72 \mathrm{~h}$ to evaluate cell viability (B) or apoptotic cells $(\mathbf{C})$. Cell viability was determined using the MTT assay and results are mean+S.E.M. attenuances ('O.D.') at $450 \mathrm{~nm}$. Apoptotic cells were evaluated as the percentage of annexin V-positive cells. $* P<0.05 ; * * P<0.01$; $* * * P<0.001$ (one-way ANOVA).

Th22/Th1 Tcc showed the ability to induce a major B-cell production of IgM compared with the other subsets of IL22 $2^{+}$Tcc, whereas the primary inducer of IgG were the Th22/Th1 Tcc. None of the IL- $22^{+}$subsets was able to induce IgE production, whereas all IL-22-producing Th subsets induced similar amounts of IgA (Figure 2B).

Regarding the cytotoxic potential, all of the different IL22 ${ }^{+}$ subsets exhibited low levels of granzyme A expression, as expected, with only the Th22/Th1 and Tc22/Tc1 Tcc displaying granzyme A expression of approximately $20 \%$ or slightly more (Figure $2 \mathrm{C}$ ). We found analogous results regarding the ability to induce apoptosis; all of the IL-22-producing Tcc displayed a low percentage of annexin V-binding cells $(<5 \%)$. Only the Tcc (as $\mathrm{CD}^{+}$or $\mathrm{CD} 8^{+}$) with a Th22/Th1 profile displayed a higher percentage (Figure 2D).

\section{IL-22 reduced IFN- $\gamma$-induced apoptosis in pancreatic cells}

As the majority of TILs produce IL-22 in combination with IFN$\gamma$, we evaluated the effect of IL-22 alone or in the presence of IFN- $\gamma$ on the human pancreatic tumour cell line L3.6pl, which is a highly metastatic tumour cell line [32], the cells of which express IL-22 receptor on their membrane (Figure 3A). IL-22 alone increases the cell viability of L3.6pl cells (Figure 3B); as expected, IFN- $\gamma$ treatment reduced cell viability (Figure 3B) and induced strong apoptosis (Figure 3C) of L3.6pl cells. Interestingly, these cytotoxic effects of IFN- $\gamma$ were significantly reduced by the presence of IL-22 (Figures 3B and 3C).

\section{Immunohistochemical evaluation of intra-tumoral IL-22+ T-cells}

To verify whether the results obtained by the ex vivo model reflected a real situation, the presence of $\mathrm{CD}^{+}{ }^{+} \mathrm{IL}-22^{+}$cells infiltrating $P D A C$ tissues was evaluated using immunohistochemistry. Among the infiltrating $\mathrm{CD}^{+}$T-cells (Figure 4A), $\mathrm{CD}^{+}{ }^{+}$T-cells were predominant compared with the $\mathrm{CD} 8^{+} \mathrm{T}$-cells (results not shown). Figures 4(B) and 4(C) only show representative images of the $\mathrm{T}-\left(\mathrm{CD}^{+} / \mathrm{CD}^{+}\right)$cell infiltration. FoxP3 ${ }^{+}$cells (Figure 4E), as well as PD- $1^{+}$cells (Figure 4F), were more frequently observed, suggesting that regulatory or activated $\mathrm{CD} 4^{+}$T-cells had infiltrated the PDAC tissues. Finally, we documented that the number of $\mathrm{CD}^{+}{ }^{+}$T-cells co-expressing IL-22 (Figure 4I) was higher in the neoplastic tissue. Table 2 shows the number of inflammatory cells which we assessed per high power field. Comparing the PDAC tissue with the surrounding healthy mucosa, we noted an increased number of $\mathrm{CD}^{+}, \mathrm{FoxP}^{+}, \mathrm{PD}-1^{+}$and, especially, IL- $22^{+}$T-cells in the tumour tissue. Finally, we also documented that the number of IL-22-producing Tcc, isolated in a single patient, significantly correlated $(P=0.0076)$ with the number of tumour-infiltrating IL-22+ cells, thus creating an important link between the in vitro and in vivo data.

\section{Th22 cells increase in the peripheral blood of PDAC patients}

Finally, the frequency of Th22 cells was assessed in the peripheral blood of PDAC patients and 30 healthy subjects by flow cytometry. After gating $\mathrm{CD}^{+}{ }^{+}$cells, we identified three different groups of IL-22-producing cells, namely one group producing IL-22 alone (termed Th22 cells), one co-producing IFN- $\gamma$ and the last co-producing IL-17. The percentage of Th22 cells in the peripheral blood of PDAC patients was significantly higher than in age-matched healthy donors (Figure 5A). The expansion of Th22 cells was accompanied by the increase of IL-22/IFN$\gamma$-co-producing (Figure 5B) and IL-22/IL-17-co-producing (Figure 5C) $\mathrm{CD}^{+}$T-cells. However, the Th22 cell subset was the highest IL-22-producing group in the peripheral blood.

\section{Clinical relevance of Th22 cells in PDAC patients}

The statistical analysis showed that IL-22-producing Tcc positively correlated with TNM staging (Figure 6A) and metastases 

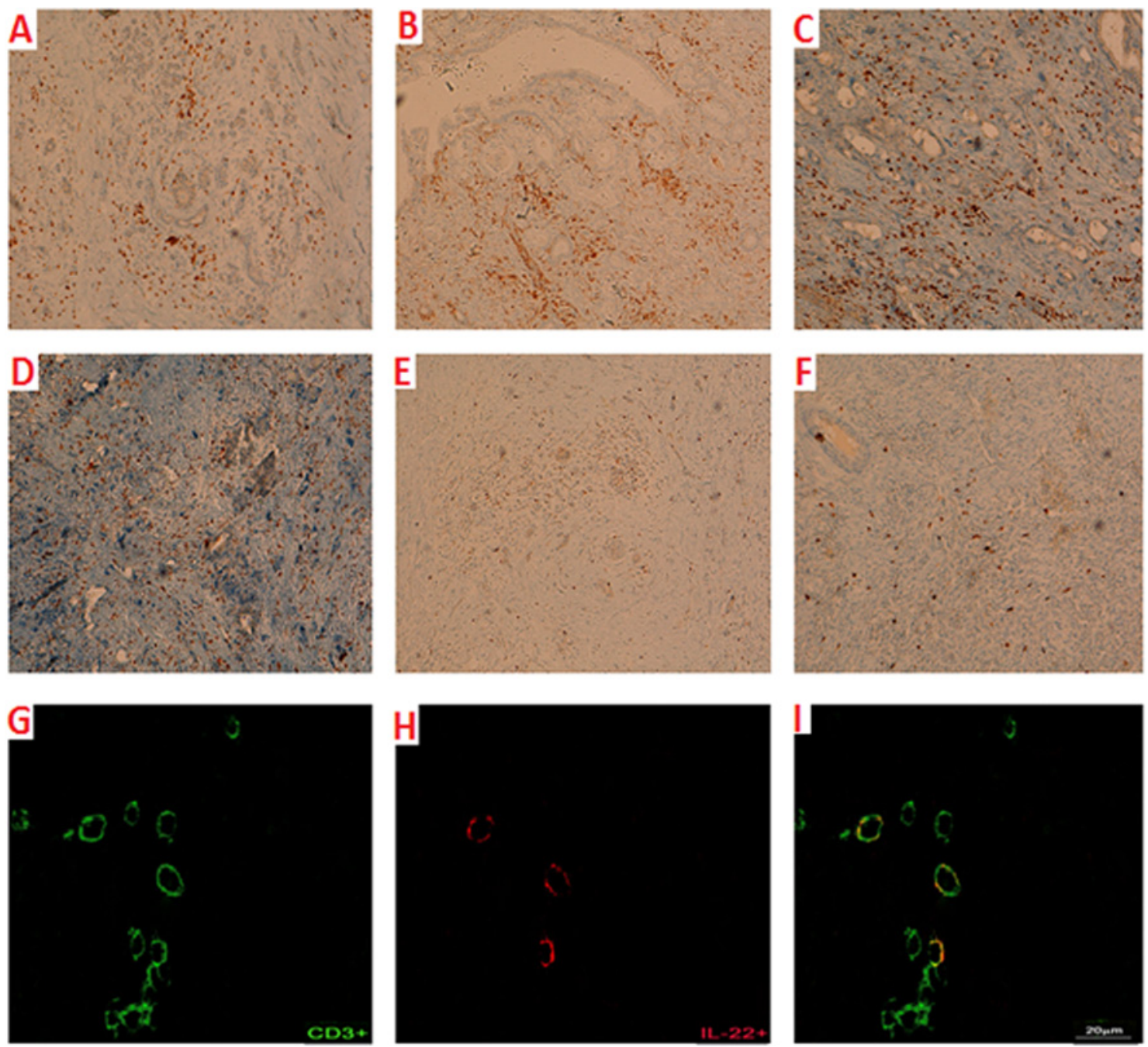

Figure 4 Immunohistochemical analysis of PDAC tissues

Surgically resected PDAC tissues were immunohistochemically stained. CD3 (A): lymphoid aggregation around PDAC was mainly composed of $\mathrm{CD}^{+}{ }^{+}$T-cells. CD4 (B): the majority of lymphoid aggregation was $\mathrm{CD}^{+}{ }^{+}$T-cells. CD8 (C): the number of $\mathrm{CD}^{+} \mathrm{T}$-cells was small compared with that of $\mathrm{CD} 4^{+}$T-cells shown in (B). Most T-cells were IL-22-positive (D), some were FoxP3-positive (E) (nuclear expression) and some were PD-1-positive (F). Magnification $\times 10$ high power field. In the lower panels are digital images, obtained using an epifluorescence Zeiss Axioskop microscope equipped with a $\times 63$ oil-immersion objective, of $\mathrm{CD}^{+}{ }^{+}$T-cells $(\mathbf{G}), \mathrm{IL}-22^{+}$cells $(\mathbf{H})$ and $\mathrm{CD}^{+}{ }^{+} \mathrm{IL}-22^{+}$T-cells $(\mathbf{I})$. The images are from tissue of different patients and are representative images of high/low-expressing samples for each marker.

(Figure 6B), but were not related to the sex or tumour size (results not shown). Taken together, these results suggest that IL-22 expression by T-cells is closely associated with PDAC progression and with the patient outcome. To test this hypothesis, we evaluated whether the number of Th22 Tcc negatively correlated with the survival of PDAC patients. The patients were divided into two groups on the basis of the percentage of intra-tumoral IL-22producing Tcc, either (i) $<50 \%$ or (ii) $\geqslant 50 \%$ (Table 1). KaplanMeier analysis revealed that the patients of group (i) showed a better survival compared with group (ii) $(P<0.0001)$, suggesting a negative correlation between the percentage of IL-22-secreting Tcc and a better outcome of the disease (Figure 6C). In other words, elevated expression of intra-tumoral Th22 correlates with PDAC progression and is a predictor of poor patient survival.

\section{DISCUSSION}

IL-22 is a member of the IL-10 family of cytokines produced by T-cells and innate lymphoid cells [33]. The distribution of the two IL-22 receptors, IL-22R1 and IL-10R2, indicates that the most important target cells of IL-22 reside in the skin, digestive system (pancreas and liver), lungs, and kidney. In general, the IL-22 signalling pathway orchestrates mucosal immune responses and tissue regeneration through pleiotropic effects, including prosurvival signalling, cell migration, dysplasia and angiogenesis [34]. Although these functions can prevent the initial establishment of tumours, they can also be exploited by aggressive cancers to enhance tumour growth and metastasis. In fact, as well as being implicated in the pathogenesis of many autoimmune and 
Table 2 Inflammatory features of PDAC tissue and surrounding healthy pancreas

The number of each inflammatory cells was assessed per high power field.

\begin{tabular}{|c|c|c|c|c|c|}
\hline Patient & $\begin{array}{l}\text { Degree of } \\
\text { inflammation }\end{array}$ & $\begin{array}{l}\text { CD4 tumour/healthy } \\
\text { mucosa }\end{array}$ & $\begin{array}{l}\text { FoxP3 tumour/healthy } \\
\text { mucosa }\end{array}$ & $\begin{array}{l}\text { PD-1 tumour/healthy } \\
\text { mucosa }\end{array}$ & $\begin{array}{l}\text { IL-22 tumour/healthy } \\
\text { mucosa }\end{array}$ \\
\hline 01.PDAp & Mild & $>100 />100$ & $<10 /<10$ & $<5 /<5$ & $38 / 27$ \\
\hline 02.PDAp & Moderate & $54 / 62$ & $58 / 22$ & $14 / 6$ & $45 / 31$ \\
\hline 03.PDAp & Severe & $83 / 80$ & $<10 /<10$ & $41 / 27$ & $62 / 48$ \\
\hline 04.PDAp & Severe & $>100 />100$ & $24 /<10$ & $10 /<5$ & $73 / 49$ \\
\hline 05.PDAp & Severe & $99 / 62$ & 32 & $55 / 33$ & $77 / 59$ \\
\hline 06.PDAp & Severe & $88 / 72$ & $<10 /<10$ & $<5 /<5$ & $65 / 51$ \\
\hline 07.PDAp & Mild & $>100 />100$ & $37 / 20$ & $<5 /<5$ & $18 / 8$ \\
\hline 08.PDAp & Severe & $98 / 82$ & $25 / 15$ & $44 / 25$ & $63 / 48$ \\
\hline 09.PDAp & Mild & $>100 />100$ & $15 /<10$ & $21 / 8$ & $72 / 54$ \\
\hline 10.PDAp & Severe & $80 / 63$ & $<10 /<10$ & $12 /<5$ & $61 / 53$ \\
\hline 11.PDAp & Moderate & $>100 />100$ & $22 / 10$ & $8 /<5$ & $61 / 49$ \\
\hline 12.PDAp & Mild & $71 / 82$ & $13 /<10$ & $12 /<5$ & $38 / 29$ \\
\hline 13.PDAp & Severe & $>100 / 82$ & $22 / 15$ & $15 / 6$ & $70 / 56$ \\
\hline 14.PDAp & Mild & $52 / 72$ & $48 / 34$ & $<5 /<5$ & $55 / 46$ \\
\hline 15.PDAp & Moderate & $>100 />100$ & $28 / 17$ & $19 / 8$ & $47 / 38$ \\
\hline 16.PDAp & Mild & $63 / 75$ & $11 /<10$ & $22 / 15$ & $22 / 15$ \\
\hline 17.PDAp & Moderate & $>100 />100$ & $32 / 20$ & $38 / 24$ & $45 / 36$ \\
\hline 18.PDAp & Severe & $88 / 63$ & $<10 /<10$ & $<5 /<5$ & $65 / 54$ \\
\hline 19.PDAp & Severe & $99 / 74$ & $18 / 11$ & $16 / 6$ & $79 / 57$ \\
\hline 20.PDAp & Mild & $>100 />100$ & $35 / 21$ & $13 /<5$ & $68 / 51$ \\
\hline 21.PDAp & Severe & $>100 />100$ & $<10 /<10$ & $25 / 16$ & $72 / 49$ \\
\hline 22.PDAp & Moderate & $>100 />100$ & $28 / 21$ & $14 / 8$ & $76 / 51$ \\
\hline 23.PDAp & Severe & $88 />100$ & $22 / 12$ & $15 / 7$ & $67 / 53$ \\
\hline 24.PDAp & Mild & $72 / 85$ & $12 /<10$ & $<5 /<5$ & $54 / 42$ \\
\hline 25.PDAp & Moderate & $>100 />100$ & $<10 /<10$ & $31 / 20$ & $19 / 8$ \\
\hline 26.PDAp & Moderate & $84 />100$ & $18 /<10$ & $28 / 16$ & $23 / 15$ \\
\hline 27.PDAp & Moderate & $>100 />100$ & $27 / 18$ & $12 / 7$ & $75 / 52$ \\
\hline 28.PDAp & Severe & $>100 />100$ & $<10 /<10$ & $<5 /<5$ & $78 / 49$ \\
\hline 29.PDAp & Mild & $>100 />100$ & $<10 /<10$ & $18 / 6$ & 49/31 \\
\hline 30.PDAp & Moderate & $68 / 78$ & $14 /<10$ & $23 / 10$ & $71 / 59$ \\
\hline
\end{tabular}

A)

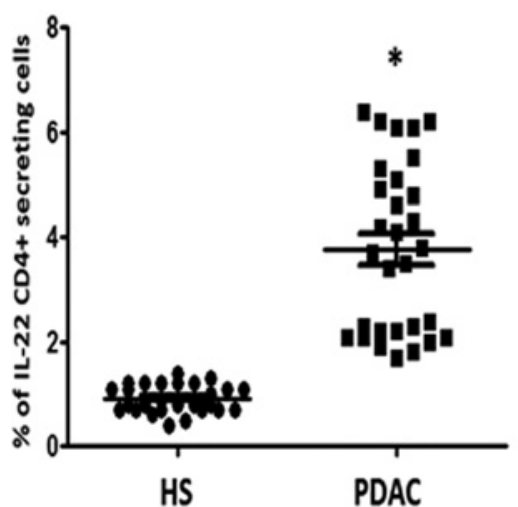

B)

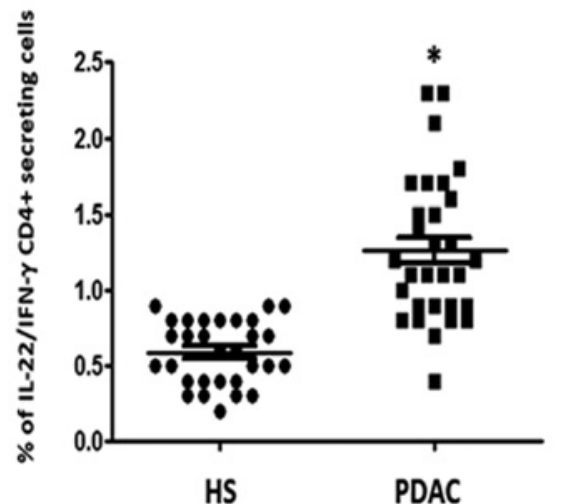

C)

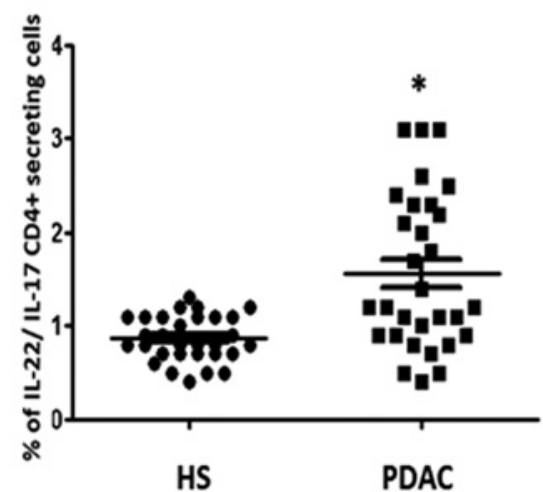

Figure 5 IL-22-producing cells in the peripheral blood of PDAC

Ex vivo FACS analysis of cytokine production from CD4 ${ }^{+}$T-cells in healthy subjects (HS) and in PDAC patients stimulated for $5 \mathrm{~h}$ with PMA and ionomycin in the presence of BFA. Results are the percentages of IL-22-producing CD4 ${ }^{+}$cells in the peripheral blood. $* P<0.001$. 
A)

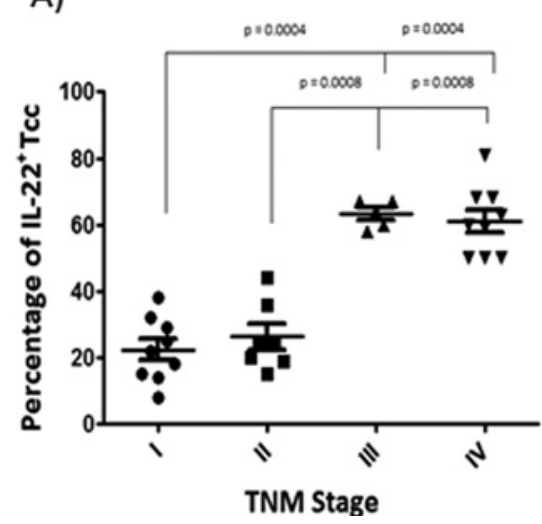

B)

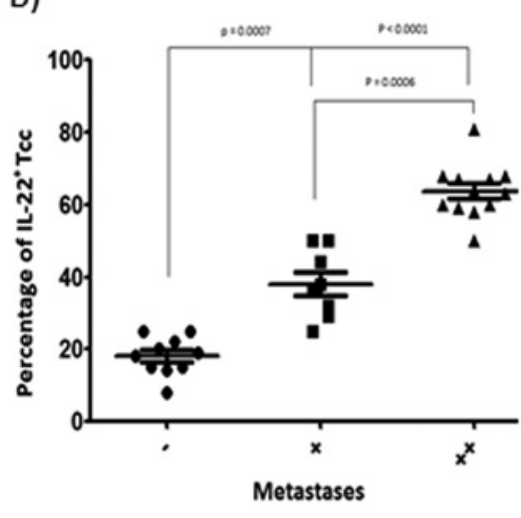

C)

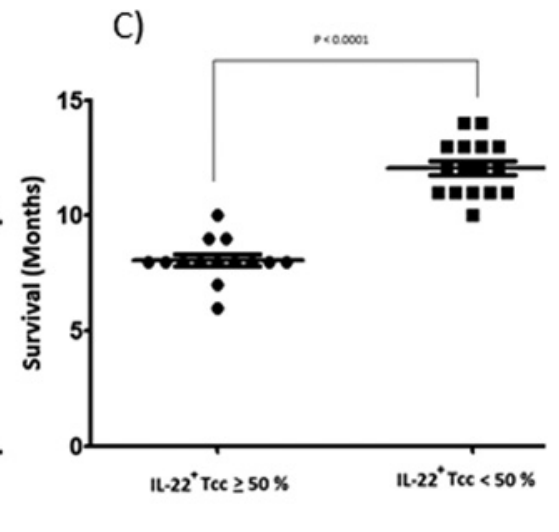

Figure 6 Correlation between clinical parameters of patients and number of Th22 Tcc

Correlation between the percentages of Th2 2 cells with TNM stage (A) and presence of metastases (B). The increased number of IL-22 $2^{+}$TILs positively and significantly correlates with TNM PDAC staging and number of metastases: - , no metastases, + , metastases in one site, ++ , multisite metastases. (C) To correlate the survival of PDAC patients with the number of Th22 Tcc, we divided the patients into two groups: (i) patients with Th22 Tcc ( $\geqslant 50 \%$ ), and (ii) the patients with Th22 Tcc (<50\%). Correlating the two groups by the Kaplan-Meier curve, we observed that group (ii) showed significantly $(P<0.0001)$ better survival compared with group (i).

inflammatory diseases, such as psoriasis [35] and rheumatoid arthritis [22], IL-22 has been associated with cancer progression, including hepatocellular carcinoma [36] and gastric cancer [24]. However, the potential role of IL-22 and especially Th22 (the major source of IL-22) in PDAC is far from clear.

In line with immunohistochemical analysis, which revealed the presence of $\mathrm{CD}^{+}{ }^{+} \mathrm{IL}-22^{+}$cells in neoplastic tissue, we demonstrated that the number of IL-22-producing $\mathrm{CD}^{+}$and $\mathrm{CD} 8^{+} \mathrm{Tcc}$ isolated from PDAC patients was significantly elevated in PDAC tissues compared with the surrounding healthy pancreas and, of note, that the number of IL-22-producing Tcc significantly correlated with the number of tumour-infiltrating IL-22+ T-cells. In other words, the number of IL-22+ ${ }^{+}$Tcc reflects the in vivo situation. In addition, we demonstrated, for the first time, that the IL-22-producing $\mathrm{Tcc}\left(\right.$ as $\mathrm{CD}^{+}$or $\mathrm{CD}^{+}$) isolated from PDAC tissue significantly produced higher IL-22 levels compared with IL- $22^{+}$Tcc isolated from the healthy pancreas. This finding suggests that the high number of IL-22-producing T-cells can be associated with PDAC progression and, in accordance with other studies [28,29], Th22 Tcc positively correlated with TNM staging and metastases. IL-22 improves the invasive ability of pancreatic cancer cell lines by increasing MMP9 (matrix metalloproteinase 9), and the association between IL-22 and poor prognosis is attributable to the increased cancer cell mobility and metastatic potential [29].

IL-22 can be produced by different T-cell subpopulations, in particular by the CD4 ${ }^{+}$T-cells: Th22, Th17 and Th1 [37]. Therefore, in order to evaluate the nature of the different IL22-producing Tcc that have infiltrated the neoplastic tissue, we characterized the cytokine profile of each single IL-22-producing Tcc. We observed that some CD4 ${ }^{+}$Tcc only produced IL-22, but the majority of them co-produced IFN- $\gamma$ alone or with IL-17, and similarly only five out of the $33 \mathrm{CD}^{+} \mathrm{Tcc}$, secreted IL-
22 alone, whereas many co-produced IFN- $\gamma$ or both IFN- $\gamma$ and IL-17. In conclusion, we have shown, for the first time, that in PDAC patients, the major intra-tumoral source of IL-22 is the T-cell subset with a Th1 profile.

Notably, as further confirmation of these ex vivo data, we also documented a similar trend in vivo; in detail, we showed that expansion of Th22 cells in the peripheral blood of PDAC patients was accompanied by an increase in IL-22/IFN- $\gamma$-co-producing and IL-22/IL-17-co-producing CD4 ${ }^{+}$T-cells.

As most of the IFN- $\gamma$-producing Tcc are able to exert perforinmediated cytotoxicity, we assessed the cytolytic potential of IL$22^{+}$Tcc and, as expected, only the Th22/Th1 Tcc showed a satisfactory expression of granzyme A, whereas the remaining different IL-22-producing Tcc subsets exhibited low levels of granzyme A. In addition, we registered analogous data about the ability to induce apoptosis: of all IL- $22^{+}$Tcc, only those coproducing IFN- $\gamma$ (Th22/Th1) displayed a significant percentage of annexin V-binding cells.

Indeed, as we have shown that PDAC cells express IL-22R, they are responsible for the anti-apoptotic effect of IL-22. We have shown that IFN- $\gamma$ induced the apoptosis of PDAC cells and that this apoptosis was antagonized by the addition of IL-22.

Taken together, these data support the hypothesis that IL-22 favours PDAC progression by inhibiting IFN- $\gamma$-induced apoptosis. The Il-22 production by intra-tumoral Th1/Th22 cells during PDAC progression may therefore neutralize the anti-tumour effect of Th1-polarized T-cells, protecting the cancer cells by the pro-apoptotic effect of IFN- $\gamma$ [38].

Finally, to complete the functional characterization of intra-tumoral IL-22+ Tcc, we evaluated their ability to assist antibody production by B-cells. In agreement with previous studies [8], all of the different Th22 subsets of Tcc were unable to induce assistance for the production of $\operatorname{IgE}$, but had 
a similar ability to induce IgA. In addition, both $\mathrm{Th} 22 / \mathrm{Th} 2$ and Th22/Th1 Tcc induced IgM production, whereas only the Th22 with a Th1 profile displayed an ability to induce IgG. In other words, IL-22 does not seem to affect the isotype switch of antibodies.

In summary, our results highlight the well-established dual role of the anti-tumour immune response in PDAC patients. Indeed, Th1 lymphocytes usually play an effector role against tumour cells by assaulting them and then blocking tumour growth $[31,39,40]$. Instead, in this context, the same Th1 cells, which produce IL-22, could promote tumour progression, as demonstrated recently in the pathogenesis of arthritis [41]. It is well known that the pro-survival and proliferative effects of IL-22 are utilized by many cancers; in particular, lung and liver cancers appear to be particularly sensitive to these effects $[36,42,43]$. In addition, IL-22 can promote carcinogenesis by favouring angiogenesis $[44,45]$ or enhancing immune evasion by tumours [45]. PDAC cells themselves secrete VEGF (vascular endothelial growth factor) and TGF- $\beta$ (transforming growth factor $\beta$ ) and IL-10 in response to IL-22 stimulation [45].

Finally, most importantly, our findings also shed light on the clinical relevance of Th22 cells in PDAC. We found that an increased frequency of Th22 cells correlated with TNM staging and with an unfavourable outcome of the disease, thus the number of IL-22-producing Tcc negatively correlated with PDAC patient survival.

Pancreatic cancer has a dismal 5-year survival rate of $<5 \%$, partly because most patients are diagnosed when the disease is already at an advanced stage, and partly because only $20 \%$ of patients have local resectable tumours $[46,47]$. Increased responsiveness to IL-22 may be the tipping point which separates resectable tumours from incurable and metastasized cancers (often already present at diagnosis). One study showed that the expression of both IL-22 and IL-22R1 was elevated in sections of PDAC tissue and predicted poorer patient survival [29]. However, a different group found that IL-22R1 was more poorly expressed in patients with PDAC compared with normal controls [48]. Primary cells and metastases of oral squamous cell carcinomas showed intense staining for IL-22R $\alpha 1$ [49]. Nonetheless, a chromosomal loss of the region IL-22R $\alpha 1$ was also found in a cohort of Sudanese patients, but not in Norwegian patients of the same study [50], mirroring the discrepancy between the results in immunohistochemical observation and array comprehensive genomic hybridization for pancreatic cancer. These data reveal how differences in genotypes between ethnic groups may affect the significance of IL-22 in a given cancer. IL-22R1 may also be more affected specifically in buccal oral squamous cell carcinoma, which the majority of Sudanese patients had, but was absent from the Norwegian cohort.

In conclusion, our data demonstrate that all IL-22-producing T-cells are significantly increased in pancreatic cancer. Furthermore, these increases positively correlated with TNM staging of PDAC and poorer patient survival. These novel findings suggest that Th22 cells may participate in PDAC pathogenesis, that the monitoring of Th22 can be a good diagnostic parameter and, finally, that blockade of IL-22 signalling may represent a viable method for anti-PDAC therapies.

\section{CLINICAL PERSPECTIVES}

- The principal sources of IL-22 are Th22 cells, which secrete only IL-22 or other cytokines such as IL-17 or IFN- $\gamma$. Intratumoral IL-22 levels were elevated in PDAC (pancreatic ductal adenocarcinoma). However, the nature, role and clinical relevance of Th22 remain unknown.

- We have shown that in PDAC patients, cytotoxic IFN- $\gamma+$ Th22 cells are the major intra-tumoral source of IL-22, which induce apoptosis, and are antagonized by IL-22. The increased levels of Th22 positively correlated with TNM and poorer patient survival.

- Elucidation of how IL-22 regulates the pathogenesis of PDAC is important, and may help to identify a new target for developing innovative PDAC treatments.

\section{AUTHOR CONTRIBUTION}

Elena Niccolai, Amedeo Amedei and Francesco Novelli conceived and designed the study, and drafted the paper. Elena Niccolai, Simona Rolla, Francesca Castiglione, Federica Ricci, Marisa Benagiano and Alessandro Pini acquired experimental data. Antonio Taddei, Paolo Bechi, Lapo Bencini, Maria Novella Ringressi, Andrea Coratti, Fabio Cianchi, Daniele Giordano and Maria Antonietta Satolli were involved in enrolment and obtaining clinical data of patients. Elena Niccolai, Mario Milco D’Elios, Daniele Bani, Simona Rolla, Francesco Novelli and Amedeo Amedei analysed and interpreted data. Amedeo Amedei, Francesco Novelli and Domenico Prisco critically revised the paper.

\section{ACKNOWLEDGEMENTS}

We thank Radhika Srinivasan for a critical reading of the paper before submission.

\section{FUNDING}

This work was supported by the Italian Ministry of University and Research (PRIN 2009), Cassa di Risparmio Foundation, the Associazione Italiana Ricerca sul Cancro [grant number 15232 and 5 per mille grant number 12182), University of Turin-Progetti Ateneo 2014-Compagnia di San Paolo (PC-METAIMMUNOTHER), Cariplo Foundation, Fondazione Ricerca Molinette and Fondazione Ursula e Giorgio Cytron.

\section{REFERENCES}

1 Jemal, A., Bray, F., Center, M.M., Ferlay, J., Ward, E. and Forman, D. (2011) Global cancer statistics. CA Cancer J. Clin. 61, 69-90 CrossRef PubMed

2 Hartwig, W., Werner, J., Jäger, D., Debus, J. and Büchler, M.W. (2013) Improvement of surgical results for pancreatic cancer. Lancet Oncol. 14, e476-e485 CrossRef PubMed

3 Kolodecik, T., Shugrue, C., Ashat, M. and Thrower, E.C. (2014) Risk factors for pancreatic cancer: underlying mechanisms and potential targets. Front. Physiol. 4, 415 CrossRef PubMed

4 Candido, J. and Hagemann, T. (2013) Cancer-related inflammation. J. Clin. Immunol. 33 Suppl., S79-S84 CrossRef PubMed 
5 Lin, W.W. and Karin, M. (2007) A cytokine-mediated link between innate immunity, inflammation, and cancer. J. Clin. Invest. 117, 1175-1183 CrossRef PubMed

6 Witte, E., Witte, K., Warszawska, K., Sabat, R. and Wolk, K. (2010) Interleukin-22: a cytokine produced by T, NK and NKT cell subsets, with importance in the innate immune defense and tissue protection. Cytokine Growth Factor Rev. 21, 365-379 CrossRef PubMed

7 Wu, R.W., Li, J., Kodangattil, S.R., Luxenberg, D.P., Bennett, F., Martino, M., Collins, M., Dunussi- Joannopoulos, K., Gill, D.S., Wolfman, N.M. et al. (2008) IL-22R, IL-10R2, and IL-22BP binding sites are topologically juxtaposed on adjacent and overlapping surfaces of IL-22. J. Mol. Biol. 382, 1168-1183 CrossRef PubMed

8 Lécart, S., Morel, F., Noraz, N., Pène, J., Garcia, M., Boniface, K., Lecron, J.C. and Yssel, H. (2002) IL-22, in contrast to IL-10, does not induce Ig production, due to absence of a functional IL-22 receptor on activated human B cells. Int. Immunol. 14, 1351-1356 CrossRef PubMed

9 Radaeva, S., Sun, R., Pan, H.N., Hong, F. and Gao, B. (2004) Interleukin 22 (IL-22) plays a protective role in T cell-mediated murine hepatitis: IL-22 is a survival factor for hepatocytes via STAT3 activation. Hepatology 39, 1332-1342 CrossRef PubMed

10 Wolk, K., Witte, E., Wallace, E., Döcke, W.D., Kunz, S., Asadullah, K., Volk, H.D., Sterry, W. and Sabat, R. (2006) IL-22 regulates the expression of genes responsible for antimicrobial defense, cellular differentiation, and mobility in keratinocytes: a potential role in psoriasis. Eur. J. Immunol. 36, 1309-1323 CrossRef PubMed

11 Nagalakshmi, M.L., Rascle, A., Zurawski, S., Menon, S. and de Waal Malefyt, R. (2004) Interleukin-22 activates STAT3 and induces IL-10 by colon epithelial cells. Int. Immunopharmacol. 4, 679-691 CrossRef PubMed

12 Aggarwal, S., Xie, M.H., Maruoka, M., Foster, J. and Gurney, A.L. (2001) Acinar cells of the pancreas are a target of interleukin-22. J. Interferon Cytokine Res. 21, 1047-1053 CrossRef PubMed

13 Shioya, M., Andoh, A., Kakinoki, S., Nishida, A. and Fujiyama, Y. (2008) Interleukin 22 receptor 1 expression in pancreas islets. Pancreas 36, 197-199 CrossRef PubMed

14 Sanos, S.L., Bui, V.L., Mortha, A., Oberle, K., Heners, C., Johner, C. and Diefenbach, A. (2009) ROR $\gamma$ t and commensal microflora are required for the differentiation of mucosal interleukin 22-producing NKp46 ${ }^{+}$cells. Nat. Immunol. 10, 83-91 CrossRef PubMed

15 Takatori, H., Kanno, Y., Watford, W.T., Tato, C.M., Weiss, G. Ivanov, I.I., Littman, D.R. and O'Shea, J.J. (2009) Lymphoid tissue inducer-like cells are an innate source of IL-17 and IL-22. J. Exp. Med. 206, 35-41 CrossRef PubMed

16 Goto, M., Murakawa, M., Kadoshima- Yamaoka, K., Tanaka, Y., Nagahira, K., Fukuda, Y. and Nishimura, T. (2009) Murine NKT cells produce Th17 cytokine interleukin-22. Cell. Immunol. 254, 81-84 CrossRef PubMed

17 Nograles, K.E., Zaba, L.C., Shemer, A., Fuentes-Duculan, J., Cardinale, I., Kikuchi, T., Ramon, M., Bergman, R., Krueger, J.G. and Guttman-Yassky, E. (2009) IL-22-producing “T22" T cells account for upregulated IL-22 in atopic dermatitis despite reduced IL-17-producing TH17 T cells. J. Allergy Clin. Immunol. 123, 1244-1252 CrossRef PubMed

18 Fujita, H., Nograles, K.E., Kikuchi, T., Gonzalez, J., Carucci, J.A. and Krueger, J.G. (2009) Human Langerhans cells induce distinct IL-22-producing $\mathrm{CD}^{+} \mathrm{T}$ cells lacking IL-17 production. Proc. Natl. Acad. Sci. U.S.A. 106, 21795-21800 CrossRef PubMed

19 Chung, Y., Yang, X., Chang, S.H., Ma, L., Tian, Q. and Dong, C. (2006) Expression and regulation of IL-22 in the IL-17-producing $\mathrm{CD}^{+}{ }^{+} \mathrm{T}$ lymphocytes. Cell Res. 16, 902-907 CrossRef PubMed

20 Zheng, Y., Danilenko, D.M., Valdez, P., Kasman, I., Eastham-Anderson, J., Wu, J. and Ouyang, W. (2007) Interleukin-22, a $T_{H} 17$ cytokine, mediates IL-23-induced dermal inflammation and acanthosis. Nature 445, 648-651 CrossRef PubMed
21 Kagami, S., Rizzo, H.L., Lee, J.J., Koguchi, Y. and Blauvelt, A. (2010) Circulating Th17, Th22, and Th1 cells are increased in psoriasis. J. Invest. Dermatol. 130, 1373-1383 CrossRef PubMed

22 Zhang, L., Li, J.M., Liu, X.G., Ma, D.X., Hu, N.W., Li, Y.G., Li, W., Hu, Y., Yu, S., Qu, X. et al. (2011) Elevated Th22 cells correlated with Th17 cells in patients with rheumatoid arthritis. J. Clin. Immunol. 31, 606-614 CrossRef PubMed

23 Rolla, S., Bardina, V., De Mercanti, S., Quaglino, P., De Palma, R., Gned, D., Brusa, D., Durelli, L., Novelli, F. and Clerico, M. (2014) Th22 cells are expanded in multiple sclerosis and are resistant to IFN- $\beta$; . J. Leukoc. Biol. 96, 1155-1164 CrossRef PubMed

24 Zhuang, Y., Peng, L.S., Zhao, Y.L., Shi, Y., Mao, X.H., Guo, G., Chen, W., Liu, X.F., Zhang, J.Y., Liu, T. et al. (2012) Increased intratumoral IL-22-producing $\mathrm{CD} 4^{+} \mathrm{T}$ cells and Th22 cells correlate with gastric cancer progression and predict poor patient survival. Cancer Immunol. Immunother. 61, 1965-1975 CrossRef PubMed

25 Liu, T., Peng, L., Yu, P., Zhao, Y., Shi, Y., Mao, X., Chen, W., Cheng, P., Wang, T., Chen, N. et al. (2012) Increased circulating Th22 and Th17 cells are associated with tumor progression and patient survival in human gastric cancer. J. Clin. Immunol. 32, 1332-1339 CrossRef PubMed

26 Petanidis, S., Anestakis, D., Argyraki, M., Hadzopoulou-Cladaras, M. and Salifoglou, A. (2013) Differential expression of IL-17, 22 and 23 in the progression of colorectal cancer in patients with K-ras mutation: Ras signal inhibition and crosstalk with GM-CSF and IFN- $\gamma$;. PLoS One 8, e73616 CrossRef PubMed

27 Wu, T., Cui, L., Liang, Z., Liu, C., Liu, Y. and Li, J. (2013) Elevated serum IL-22 levels correlate with chemoresistant condition of colorectal cancer. Clin. Immunol. 147, 38-39 CrossRef PubMed

28 Xu, X., Tang, Y., Guo, S., Zhang, Y., Tian, Y., Ni, B. and Wang, H. (2014) Increased intratumoral interleukin 22 levels and frequencies of interleukin 22-producing $\mathrm{CD}^{+}{ }^{+} \mathrm{T}$ cells correlate with pancreatic cancer progression. Pancreas 43, 470-477 CrossRef PubMed

29 Wen, Z., Liao, Q., Zhao, J., Hu, Y., You, L., Lu, Z., Jia, C., Wei, Y. and Zhao, Y. (2014) High expression of interleukin-22 and its receptor predicts poor prognosis in pancreatic ductal adenocarcinoma. Ann. Surg. Oncol. 21, 125-132 CrossRef PubMed

30 Warshaw, A.L. and Fernández-del Castillo, C. (1992) Pancreatic carcinoma. N. Engl. J. Med. 326, 455-465 CrossRef PubMed

31 Amedei, A., Niccolai, E., Della Bella, C., Cianchi, F., Trallori, G., Benagiano, M., Bencini, L., Bernini, M., Farsi, M., Moretti, R. et al. (2009) Characterization of tumor antigen peptide-specific T cells isolated from the neoplastic tissue of patients with gastric adenocarcinoma. Cancer Immunol. Immunother. 58, 1819-1830 CrossRef PubMed

32 Bruns, C.J., Harbison, M.T., Kuniyasu, H., Eue, I. and Fidler, I.J. (1999) In vivo selection and characterization of metastatic variants from human pancreatic adenocarcinoma by using orthotopic implantation in nude mice. Neoplasia 1, 50-62 CrossRef PubMed

33 Trifari, S. and Spits, H. (2010) IL-22-producing CD4+ T cells: middle-men between the immune system and its environment. Eur. J. Immunol. 40, 2369-2371 CrossRef PubMed

34 Wolk, K., Kunz, S., Witte, E., Friedrich, M., Asadullah, K. and Sabat, R. (2004) IL-22 increases the innate immunity of tissues. Immunity 21, 241-254 CrossRef PubMed

35 Lo, Y.H., Torii, K., Saito, C., Furuhashi, T., Maeda, A. and Morita, A. (2010) Serum IL-22 correlates with psoriatic severity and serum IL-6 correlates with susceptibility to phototherapy. J. Dermatol. Sci. 58, 225-227 CrossRef PubMed

36 Jiang, R., Tan, Z., Deng, L., Chen, Y., Xia, Y., Gao, Y., Wang, X. and Sun, B. (2011) Interleukin-22 promotes human hepatocellular carcinoma by activation of STAT3. Hepatology $\mathbf{5 4}$, 900-909 CrossRef PubMed 
37 Gurney, A.L. (2004) IL-22, a Th1 cytokine that targets the pancreas and select other peripheral tissues. Int. Immunopharmacol. 4, 669-677 CrossRef PubMed

38 Regis, G., Conti, L., Boselli, D. and Novelli, F. (2006) IFN $\gamma$ R2 trafficking tunes IFN $\gamma$-STAT1 signaling in T lymphocytes. Trends Immunol. 27, 96-101 CrossRef PubMed

39 Sideras, K., Braat, H., Kwekkeboom, J., van Eijck, C.H., Peppelenbosch, M.P., Sleijfer, S. and Bruno, M. (2014) Role of the immune system in pancreatic cancer progression and immune modulating treatment strategies. Cancer Treat. Rev. 40, 513-522 CrossRef PubMed

40 Amedei, A., Niccolai, E., Benagiano, M., Della Bella, C., Cianchi, F., Bechi, P., Taddei, A., Bencini, L., Farsi, M., Cappello, P. et al. (2013) Ex vivo analysis of pancreatic cancer-infiltrating $T$ lymphocytes reveals that ENO-specific Tregs accumulate in tumor tissue and inhibit Th1/Th17 effector cell functions. Cancer Immunol. Immunother. 62, 1249-1260 CrossRef PubMed

41 Justa, S., Zhou, X. and Sarkar, S. (2014) Endogenous IL 22 plays a dual role in arthritis: regulation of established arthritis via IFN- $\gamma$ responses. PLoS One 9, e93279 CrossRef PubMed

42 Zhang, W., Chen, Y., Wei, H., Zheng, C., Sun, R., Zhang, J. and Tian, Z. (2008) Antiapoptotic activity of autocrine interleukin-22 and therapeutic effects of interleukin-22-small interfering RNA on human lung cancer xenografts. Clin. Cancer Res. 14, 6432-6439 CrossRef PubMed

43 Ye, Z.J., Zhou, Q., Yin, W., Yuan, M.L., Yang, W.B., Xiang, F., Zhang, J.C., Xin, J.B., Xiong, X.Z. and Shi, H.Z. (2012) Interleukin 22-producing $\mathrm{CD}^{+}{ }^{+} \mathrm{T}$ cells in malignant pleural effusion. Cancer Lett. 326, 23-32 CrossRef PubMed
44 Curd, L.M., Favors, S.E. and Gregg, R.K. (2012) Pro-tumour activity of interleukin-22 in HPAFII human pancreatic cancer cells. Clin. Exp. Immunol. 168, 192-199 CrossRef PubMed

45 Eyerich, S., Eyerich, K., Pennino, D., Carbone, T., Nasorri, F., Pallotta, S., Cianfarani, F., Odorisio, T., Traidl-Hoffmann, C., Behrendt, H. et al. (2009) Th22 cells represent a distinct human T cell subset involved in epidermal immunity and remodeling. J. Clin. Invest. 119, 3573-3585 PubMed

46 Hidalgo, M. (2010) Pancreatic cancer. N. Engl. J. Med. 362, 1605-1617 CrossRef PubMed

47 Vincent, A., Herman, J., Schulick, R., Hruban, R.H. and Goggins, M. (2011) Pancreatic cancer. Lancet 378, 607-620 CrossRef PubMed

48 Crnogorac-Jurcevic, T., Chelala, C., Barry, S., Harada, T., Bhakta, V., Lattimore, S., Jurcevic, S., Bronner, M., Lemoine, N.R. and Brentnall, T.A. (2013) Molecular analysis of precursor lesions in familial pancreatic cancer. PLoS One 8, e54830 CrossRef PubMed

49 Naher, L., Kiyoshima, T., Kobayashi, I., Wada, H., Nagata, K., Fujiwara, H., Ookuma, Y.F., Ozeki, S., Nakamura, S. and Sakai, H. (2012) STAT3 signal transduction through interleukin-22 in oral squamous cell carcinoma. Int. J. Oncol. 41, 1577-1586 PubMed

50 Roman, E., Meza-Zepeda, L.A., Kresse, S.H., Myklebost, O., Vasstrand, E.N. and Ibrahim, S.O. (2008) Chromosomal aberrations in head and neck squamous cell carcinomas in Norwegian and Sudanese populations by array comparative genomic hybridization. Oncol. Rep. 20, 825-843 PubMed 